Temtland, where severai of the localities in which the palæontological discoveries were made are surrounded by spruce forests, and where the tree grows higher up on the mountains than the fir, which is the reverse of what is generally the case. In Jemtland, therefore, the spruce clearly immigrated after the fir, and first when the principal tuff formation had ceased. Whence did the spruce immigrate into Sweden? It cannot have been from the south or from Denmark, for remains of the tree are totally absent in that country's well.explored peatbogs, neither does it belong to Denmark's present wild flora. Neither can the spruce have come from the Jiritish Isles. Certain'y it appears from palæontological evidence that the spruce existed in England before the Ice age, but it appears to have been extinguished during that age, as it is absent from the post-glacial deposits as well as from the IBritish flora of the present day. Finally, the scarcity of the spruce in the western parts of South-Eastern Norway fully proves that it did not immigrate from the west. There cannot, therefore, be the slightest doubt that the spruce immigrated into Sweden from the east. This assumption corresponds entirely with the present extension of the tree east of the Baltic. But this immigration cannot have taken place via Northern Sweden around the Gulf of Bothnia, as this part can be supposed to have had only at a later period a climate mild enough for its existence. It is more probable that the immigration tork place, vid the Island of Gothland on the south east coast, or witi the Aland Islands, off Central Sweden, and that the spruce afterwards spread north, west, and southwards.

It may be mentioned, by the way, that the sprice existed in the neighbourliood of Enköping at the time when Lake Mälaren was a bay of the Baltic, and the sea covered the spot where the town is now situated. Of great importance with regard to this point is the discovery recently made $b \%$ Dr. $\mathrm{H}$. Munthe, that the spruce was found in Gothland at a time so far remote that the division of land and sea then was wholly different from that which at present exists. This seems to speak for the immigration cf the sprace by this road. Further, Dr. R. Hult, of Helsingfors, last summer discovered in West Nyland, in Finland, sub-fossil remains of spruce in a stratum which he estimates to be older than the remains of spruce found in Scandinavia, and he therefore considers that the spruce immigrated fro a Finland.

Considering the present and past extension of the spruce in Europe, one might be inclined to assume that the true home of this tree was Scandinavia, whence it was driven in the Glacial age, but this, it is now being demonstrated, was not the case.

Now, the spruce, in spite of its relatively late immigation, has in Sweden spread greatly, forming huge forests; and we might be disposed to conclucle that in its turn it would extinguish other species. Experience from our forests goes to prove that this is really the case. Thus, from Southern Sweden we know from the researches of Dr. R. Hult in Blekinge that the spruce (except in dry localities) generally extinguishes the fir. And reports by Herr C. G. IIolmerz and Herr Th. Ortenblad show that this is also the case in Norrbotten, where "the spruce in all more favoured localities wedges itself in between firs and birches, and finally exterminates its predecessors in occupation." Even the oak is ousted by the spruce. Prof. Elias Fries states that " the spread of our noblest foliage tree is being arrested in recent times. In a primæval spruce forest, where there is no more oak in the locality, I have found below an immence layer of moss oak trunks of such dimensions that I doubt whether there are their equal in all Sweden." In Blekinge also similar facts have been brought to light, and recently Prof. F. R. Kjellman expressed the opinion that "the oak flora formerly had a greater extension in our country, but has been thrust aside by the spruce."

Although the spruce is victorious over some species, it is unable to conquer the beech. Therefore there is little chance that the spruce will take possession of our southern counties.

In conclusion, as the result of the known palæontological facts respecting the immigration of our flora, we are able to express the opinion that the greatest part of the Arctic flora, as the inland ice melted, immigrated from the south; and that, of the various forest trees, the birch, aspen, and fir came by the same road, forming the country's oldest forests. From the south, too, we must assume that salix, mountain ash, mountain elm, hazel, lime, with accompanying shrubs, certain willows, guelder rose, Rhammus frangula, Cornus sanguinea, and the hawthorn came, and from the same quarter, at a later period, the common ash, oak, and ivy. Furthermore, later still, the beech and the hornbeam, with accompanying shrubs, came from this quarter. The spruce and the beech both immigrated late, but the former from the east. These two forest trees are at present, in different localities, the two most favoured, the beech in the south, and the spruce in all other parts as far as the northern limit of coniferous trees. But the contest between the different species of trees is no longer undisturbed. For since man settled in the land a new factor has arisen, and this factor participates both directly and indirectly in the contest. Originally slight, his influence has grown greater and greater, and the time may come when he will be the arbiter as to the trees that are to form the forests of the future.

Geological Survey of Sweden.

A. G. NATilorst.

\section{AGRICULTURAL EXPERIMENTAL STATIONS IN THE UNITED STATES.}

THE following interesting information in reference to the establishment of agricultural experimental stations in the United States is given in a memorandum recently issued by the Agricultural Department of the Privy Council, and laid before Parlia ment. An "Office of Experiment Stations" has been instituted as a special branch of the United States Department of Agriculture. For the expense in connection therewith a sum of f2000 was voted by Congress in 1888 , to enable the Commissioner of Agriculture to carry out Section 3 of the Act of Congress of March 1887 , by which experimental stations were cstablished. This said section provides that, "in order to secnre, as far as practicable, uniformity of methods and results in the work of the said stations, it shall be the duty of the United States Commissioner of Agriculture to furnish forms, as far as practicable, for the tabulation of results of investigation or experiments; to indicate, from time to time, such lines of inquiry as to him shall sem most important; and in general to furnish such advice and assistance as will best promote the purposes of this $\Lambda$ ct. It shall be the duty of each such station annually, on or before February I, to make to the Governor of the State or Territory in which it is located, a full and detailed report of its operation, including a statement of receipts and expenditure to the said Commissioner of Agriculture, and to the Secretary of the Treasury of the United States." In I 888 an Act was passed by Congress maling an appropriation for the Department of Agriculture for the fiscal year ending June 30, 1889 , and for other purposes, appropriating frI $_{10,000}$, including the f2000 specially reserved for the Commission of Agriculture, for the purpose of endowing and assisting agricultural and experimental stations throughout the country. Besides this sum, the several States have contributed $£ 25$, o0o, making

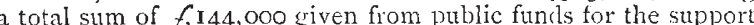
of these stations. There are now forty-six of these stations in the United States, so that, taking an average, each station will receive over $f 3000$ this year. It is said, how ever, that several of these stations have sub-stations under them, and that there are 370 trained men connected with the stations in the prosecution of scientific and practical agricultural experiments. The first agricultural experiment station in America was established in 1875 in Connecticut, and the next in California in the year following. In I879 the well-known Cornell University Station was founded, which has done so much good work, and the equally valuable Wisconsin Station in 1883 . No less than twenty-six stations were founded last year, in consequence of the inducements set forth by the Act of 1887 . In a recent Report as to the organization of these experimental stations, a list of the staff of each is given, from which list a few examples may be taken to show the extent of work that is performed, or may be performed. At the Connecticut Agricultural Station there is a director who is a Master of Arts, a vicedirector who is a Doctor of Philosophy, and a chemist. There are three other chemists who are Doctors or Bacheiors of Philosophy, a mycologist, and a practical farmer in charge of grounds and buildings. The staff of the Dakota Station is still more extensive, consisting of a director, a superintendent of the farm, a superintendent of forestry and horticultural experiments, an entomologist, an analytical chemist, a veterinarian, an accountant and stenographer, and a librarian. Upon the staff of the Iowa Station there are two chemists, one for ordinary and one for special work, a botanist for ordinary and special work, an entomologist, a veterinarian, a horticulturist, and a practical farmer. The Comell University Station staff comprises à chemist, veterinarian, botanist, and arboriculturist, a horticulturist, an entomologist, a cryptogamic botanist, besides an assistant in entomology, chemistry, veterinary 
science, and horticulture. Among the operations of these agricultural experiment stations are "fertilizer control," or the analyses of manures, the analyses of fodder and feeding-stuff; drainage experiments, feeding experiments with farm animals, observations on milk, the determination of injurious insects, with remedies against their attacks, fruit culture experiments, drinkingwater analyses, ensilage experiments, meteorology, seed-testing, analyses of soils and rocks, the culture of various plants for fodder and corn, with other useful work.

\section{SOCIETIES AND ACADEMIES.}

\section{PARIS.}

Academy of Sciences, August 26.-M. Des Cloizeaux, President, in the chair.-On the molecular tactics of the artificial macle of Iceland spar produced by Baumhauer by means of a knife, by Sir William Thomson. The substance of this paper has already been communicated to the Royal Society of Edinburgh, and will shorly be published, under the title of "Molecular 'Tactics of Crystals," in the Proceedings of the Society. The author also contributes a paper on the equilibrium of atoms, and the elasticity of solids in Boscovich's theory of matter.- Note on the orbits of shooting-stars, and on stationary radiant points, by M. F. Tisserand. A calculation of the elements (mostly parabolic) of their several orbits leads to the inference that the meteoric showers encountered by the earth at different times of the year do not all emanate from the same radiating centre, but belong to different systems proceeding from quite independent radiant points. A series of essays based on the as:umption that the orbits are not parabolic, but elliptic, lead to the same conclusion.-On the relations of atmospheric nitrogen to vegetable soil, by M. Th. Schlcesing. This is a reply to M. Berthelot's recent strictures on the author's negative results. These results are here maintained, and M. Schlœing again argues on fresh grounds that there is no fixation of nitrogen by vegetable humus except through the actual process of vegetation.-Pathogenic properties of the microbes present in malignant tumours, by $M$. Vernevil. The author still adheres to the opinion already enunciated in 1883 , that these parasites have nothing to do with the initial stage of boils, ulcers, cancer, and the like. At the same time he does not regard their presence as a matter of indifference, but admits that in certain cases they may themselves possess special pathogenic properties, in virtue of which they act on the system like septic poisons.-On the progress of the zoological station at Roscoff, by M. de LacazeDuthiers. 'The author speaks in satisfactory terms of the present condition of this station, and of the complementary establishmert at Banyuls, which have now been placed in connection with the Sorbonne. The electric light, introduced at Roscoff by the aid of private munificence, is now in perfect working order.The Eiffel Tower struck by lightning, by M. Mascart. A correct account is given of this occurrence, which took place on August I9, and exaggerated reports of which appeared in the daily papers. The conductor was struck, with the normal results, showing perfect communication with earth, and consequently complete safety of the structure from any danger on this score. Observations with the pendulun effected in Russia, by General Steibnitski. The author reports that the Russian Imperial Geographical Society is now in possession of three Repsold pendulums, with which the latitude and longitude of Karmakul in Novaya Zemlya and Archangel, the two northernmost stations in European Russia, have been accurately determined. - Occultation of Jupiter by the moon, August 7, 1889, by M. Ch. André. The results are given of the three observations taken at the Observatory of Lyons by MM. André, Le Cadet, and Marchand. None of the satellites disappeared instan taneously, as is the case with stars of the same magnitude (seventh). The disappearance of satellites III., II., and IV. occupied $I^{\prime \prime} \cdot 5, I^{\prime \prime} \cdot I$, and $0^{\prime \prime} \cdot 5$ respectively, giving for their several diameters $0^{\prime \prime} \cdot 46, \mathrm{O}^{\prime \prime} \cdot 30$, and $\mathrm{O}^{\prime \prime} \cdot 15 \cdot$ - On the angle of polarization of the moon, by M. J. J. Landerer. A method is described by means of which this element has been determined at $33^{\circ} 17^{\prime}$, a mean value resulting from eleven series of observations with probable error $\pm 7^{\prime}$. The same process is equally applicable to the planet Venus.-On the solar spots, by M. G. Sporer. Besides some brilliant protuberances, the large spot visible from June 16 to 18 was observed on the last day at I0.43 a.m. at Potsdam. But a photograph of the same taken a few minutes before the observation shows no trace of the spot which is replaced by an even depression on the solar rim exactly where the spot had been observed. An explanation is suggested of this phenomenon.--Specific heat of aqueous vapour under constant volume, by M. Ch. Antoine. For Regnault's curves of the form $x=\mathrm{A}+\mathbf{M} t_{s}-\mathbf{N} t_{s}{ }^{2}$, the author substitutes functions of the temperature $t$ and of the tension $p$, such as $x=\mathrm{B}+c t_{s}=\phi(p)$, deducing for aqueous vapour two determinations for specific heat under constant pressure and constant volume. Analogous formulas may be obtained for other vapours, such as ether, chloroform, acetone, benzene, chloricle, and sul. phice of carbon.--Papers were contributed by M. Léo Vignon on the action of water on stannic chloride; by M. G. Raulin, on the action of phosphates on the growth of cereals; by M.C. Timiriazeff, on the relation between the intensity of solar radiation and the decomposition of carbonic acid by plants; and by M. $\Lambda$ rmand Sabatier, on the zoological station at Cette.

BOOKS, PAMPHLETS, and SERIALS RECEIVED.

Marine Aquaria: R. A. R. Bennett (Gill).-Narrative of an Explorer i Tropical South Africa; $F$. Galton (Ward, Lock). - The Mathematical Theory of Electricity and Magnetism; vol, ii. Magnetism and Electrodynanics Watson and Burbury (Clarendon Press). - Bulletin of the U.S. National Museum; No. 34. The Batrachia of North America: E. D. Cope (Washing ton). - Bulletin of the U.S. National Museum; Contributions to the Natura History of the Cetaceans, a Review of the Family Delphinic to: F. W True (Washington).-Calcul des Probabilités: F. Bertrand (Paris, GauthierVillars)-Die Fosslen Pferde der Pampasformation: Dr. H Burtheister (Buenus Aires).-- Flementary Physiography and edition: Gr. H. Burmeister (Buenus Aires). - Elementary Physiography, and edition: G. Thom (Edin burgh, Thin). -The Eiffel Tower: G. Tissandier (Low) $\rightarrow$ Train, July (Macmillan). - The Esclepiad, No. 23, vol. vi.: Dr. B. W. Richardson (Longmans). - Journal of the Cor.,
vol. Parts I and 2 (Tôkyo).

\section{CONTENTS.}

Sir William Thomson's Popular Lectures. By Prof. Oliver J. Lodge, F.R.S. ${ }^{\circ}$. Political Economy. Bye Mathematical Theory of Political Economy. Musical Instruments and their Homes ... 436 Our Book Shelf:-

Madan: "Heat"

Symons: "British Rainfall,

Holmes: "Ancient Art of the Provine of C C * 437

Williamson andent Art of the Province of Chiriqui 437

Tarleton: "An Elementary Treatise on Dynamics" . . . . . . . . . . 437

Letters to the Editor:-
On some Effects of Lightning.-Captain J. P. Maclear ............. Nose-Blackening as a Preventive of Snow-Blindness. -Rev. Henry Bernard . . . . . . .

A Method of Mounting Dried Plants.--Dr. John Colour-Blindness and Defective Far-Sight among the Seamen of the Mercantile Marine . . . . . 43 St. Elmo's Fire on Ben Nevis. By A. R. . . . 439 Telescopes for Stellar Photography. I. (Iliustrated.)

By Sir Howard Grubb, F.R.S. . . . . . . . . . 44r

Notes ............... . . 444

Our Astronomical Column:-

Yale College Observatory . . . . . . . . . 448

New Minor Planet . . . . . . . . . . 448

Comet 1889 d (Brooks, July 6 ) . . . . . . . 448

Comets $1888 e$ (Barnard, September 2) and $1889 b$

(Barnard, March 3I) . . . . . . . . 448

Reduction of Rutherfurd's Photographs of the Pleiades and Præsepe perom for the Week ${ }^{\circ} 889^{\circ}$ Astronomical Phenomena for the Week 1889 September 8-14 ........... 448 Geographical Notes $\cdot 0^{-\cdots \cdot} \cdot \cdot^{\circ} \cdot \cdot^{\cdot} \cdot{ }^{\circ} 449$ Our Sensations of Motion. (Illustrated.) By Prof A. Crum Brown

On the Geological History of the Prehistoric Flora of Sweden. By Dr. A. G. Nathorst .
Agricultural Experimental Stations in the United States

Societies and Academies . . . . . . . . . . . 456 Books, Pamphlets, and Serials Received $\because . .456$ 